\title{
Melting relations of anhydrous olivine-free pyroxenite Px1 at 2 GPa
}

\author{
Giulio Borghini and Patrizia Fumagalli \\ Dipartimento di Scienze della Terra, via Botticelli 23, 20133 Milan, Italy \\ Correspondence: Patrizia Fumagalli (patrizia.fumagalli@unimi.it)
}

Received: 30 September 2019 - Revised: 4 February 2020 - Accepted: 6 March 2020 - Published: 23 March 2020

\begin{abstract}
The reaction between melt derived by mafic heterogeneities and peridotites in an upwelling mantle may form hybrid olivine-free pyroxenites. In order to evaluate the impact of these lithologies on the chemistry of primitive magmas and their ability to give rise to new mantle heterogeneities, we experimentally investigate the melting relations at $2 \mathrm{GPa}$ of the model olivine-free pyroxenite $\mathrm{Px} 1\left(X_{\mathrm{Mg}}=0.81, \mathrm{SiO}_{2}=52.9 \mathrm{wt} \%\right.$, $\left.\mathrm{Al}_{2} \mathrm{O}_{3}=11.3 \mathrm{wt} \%, \mathrm{CaO}=7.6 \mathrm{wt} \%\right)$. The subsolidus assemblage consists of clinopyroxene, orthopyroxene, and garnet. At $2 \mathrm{GPa}$, the solidus of Px 1 is located between 1250 and $1280^{\circ} \mathrm{C}$, at a temperature about $70^{\circ} \mathrm{C}$ lower than the solidus of fertile lherzolite. At increasing melt fraction, the sequence of mineral phase disappearance is garnet-clinopyroxene-orthopyroxene. Across the solidus, partial melting of Px 1 is controlled by reaction garnet + clinopyroxene $=$ liquid + orthopyroxene, and above $1300^{\circ} \mathrm{C}$, once garnet is completely consumed, by reaction clinopyroxene + orthopyroxene $=$ liquid. Orthopyroxene is the liquidus phase, and at $1480{ }^{\circ} \mathrm{C}$ olivine-free pyroxenite Px 1 is completely molten indicating a melting interval of about $200^{\circ} \mathrm{C}$. Isobaric melt productivity is similar to garnet clinopyroxenites, and it is more than 3 times that of a fertile lherzolite at $1400^{\circ} \mathrm{C}$. Px 1 partial melts cover a wide range of $X_{\mathrm{Mg}}(0.57-0.84)$, with $\mathrm{SiO}_{2}, \mathrm{Al}_{2} \mathrm{O}_{3}$ and $\mathrm{Na}_{2} \mathrm{O}$ decreasing and $\mathrm{Cr}_{2} \mathrm{O}_{3}$ increasing with the degree of melting. $\mathrm{CaO}$ content in partial melts increases as long as clinopyroxene is involved in melting reactions and decreases after its exhaustion. At $2 \mathrm{GPa}$ and for melting degrees higher than $10 \%$, Px1 produces $\mathrm{MgO}$-rich basaltic andesites matching the composition of eclogitic melts in terms of silica and alkali contents but with significantly higher $X_{\mathrm{Mg}}$ values. These melts differ from those derived from lherzolites at $2 \mathrm{GPa}$ by higher $\mathrm{SiO}_{2}$ and lower $\mathrm{CaO}$ contents. Their high silica activity makes them very reactive with mantle peridotite producing hybrid orthopyroxene-rich lithologies and residual websterites. Melt-rock reactions likely prevent direct extraction of melts produced by olivine-free pyroxenites.
\end{abstract}

\section{Introduction}

Several lines of evidence indicate that the upper mantle contains a significant fraction of mafic lithologies (e.g., Hofmann, 2007, and references therein), likely included to depth via subduction, which are expected to form eclogites at pressures above 2.0 GPa (Ringwood and Green, 1966; Allègre and Turcotte, 1986; Yasuda et al., 1994; Hirschmann and Stolper, 1996; Kogiso et al., 2004a). Even though volumetrically subordinated to ultramafic peridotites, they may play an important role in basalt generation because of their large contribution to mantle magma production as a result of their high melt productivity with respect to peridotites (e.g., Hirschmann and Stolper, 1996; Phipps Morgan, 2001; Ko- giso et al., 2003; Pertermann and Hirschmann, 2003a, b). Many ocean island basalts (OIBs) have isotopic and geochemical signatures that require the partial melting of mafic components (e.g., Hofmann, 1997, 2007; Lassiter et al., 2000; Sobolev et al., 2005, 2007; Herzberg, 2011; Mallik and Dasgupta, 2012). Moreover, there is a growing consensus that some mid-ocean ridge basalts (MORBs) derive from a heterogeneous mantle source including peridotite mixed to olivine-poor pyroxenites (Lambart et al., 2012, 2013, 2016; Borghini et al., 2017; Lambart, 2017; Brunelli et al., 2018).

Crustal-derived mafic rocks represent low-solidus mantle lithologies and start melting at higher pressure than "dry" peridotites (e.g., Yasuda et al., 1994; Pertermann and 
Hirschmann, 2003a, b; Kogiso et al., 2004a; Kogiso and Hirschmann, 2006; Yaxley and Sobolev, 2007; Spandler et al., 2008). Their partial melts are expected to react with the surrounding peridotite either modifying the composition of the rising melts (Pilet et al., 2008; Mallik and Dasgupta, 2012, 2013, 2014) or creating new hybrid rocks, called secondary or stage 2 pyroxenites (e.g., Yaxley and Green, 1998; Sobolev et al., 2005, 2007; Herzberg, 2006, 2011; Lambart et al., 2012). Heterogeneous upwelling mantle is subject to continuous events of partial melting and melt-rock reactions that potentially replace the mafic components with a compositionally wide range of hybrid lithologies, including metasomatized peridotites and variably residual pyroxenites (e.g., Yaxley and Green, 1998; Spandler et al., 2008; Rosenthal et al., 2014, 2018). Petrological studies on ultramafic massifs have interpreted some pyroxenites embedded in mantle peridotite as natural examples of secondary pyroxenites, originated through high-pressure melt-peridotite reactions (i.e., Garrido and Bodinier, 1999; Bodinier et al., 2008; Gysi et al., 2011; Marchesi et al., 2013; Borghini et al., 2013, 2016, 2019; Montanini and Tribuzio, 2015).

A large number of experimental studies have been dedicated to partial melting of pyroxenites defining a large spectrum of partial melts compositions (e.g., Yaxley and Green, 1998; Kogiso and Hirschmann, 2001; Hirschmann et al., 2003; Pertermann and Hirschmann, 2003a; Kogiso et al., 2004a; Keshav et al., 2004; Médard et al., 2006; Sobolev et al., 2007; Lambart et al., 2009, 2013). These studies emphasized the existence of the garnet-pyroxene thermal divide, defined by the enstatite-Ca-Tschermak's pyroxene (En-CaTs) plane in the pseudoternary diagram forsteriteCaTs-quartz (Fo-CaTs-Qz) projected from diopside (Di) (e.g., Kogiso et al., 2004a; Lambart et al., 2013). The divide separates two fundamental types of pyroxenites: silicaexcess (SE) pyroxenites plotting in the En-CaTs-Qz plane and silica-deficient (SD) pyroxenites contained in the EnFo-CaTs triangle (e.g., Kogiso et al., 2004a; Lambart et al., 2013) Above $2 \mathrm{GPa}$, when garnet and pyroxenes are the main residual phases, it represents a thermal barrier controlling melting relations of pyroxenites. The most relevant effect is that at $P>2 \mathrm{GPa}$ SE and SD pyroxenites generate melts in the En-CaTs-Qz and En-Fo-CaTs triangle, respectively (Kogiso et al., 2004a).

Although several experimental works focused on melting relations in SD pyroxenites and eclogites (Lambart et al., 2013, and references therein), the melting behavior of hybrid olivine-free pyroxenites has been poorly evaluated. Recently, Borghini et al. (2017) have experimentally investigated an olivine-poor SD secondary pyroxenite concluding that during the partial melting of a heterogeneous peridotitepyroxenite mantle source its involvement does not significantly impact on major element composition of primary basalts. In order to evaluate the role of olivine-free lithologies in the origin of Hawaiian OIBs, Sobolev et al. (2007) studied the melting behavior at 3.5 GPa of an olivine-free SE sec- ondary pyroxenite, whose composition was modeled as product of reaction between eclogite-derived silica-rich melts and a peridotite. The composition of partial melts produced by this olivine-free SE pyroxenite allowed one to explain the unusually high $\mathrm{NiO}$ and $\mathrm{SiO}_{2}$ contents of most parental Hawaiian magmas giving rise to a quantitative model supporting the significant role of such lithology (Sobolev et al., 2005, 2007). Indeed, olivine-free rocks have been taken into consideration as a relevant mantle component in partial melting (Mallik and Dasgupta, 2012; Lambart et al., 2012, 2013; Lambart, 2017) or as a source for refertilizing mantle melts (e.g., Pearson and Nowell, 2004; Borghini et al., 2013, 2016; Tilhac et al., 2016, 2017; Varas-Reus et al., 2018). However, their melting behavior at shallower mantle levels $(P<3.5 \mathrm{GPa})$ is currently not available. The knowledge of the composition of partial melts produced by hybrid SE pyroxenite will contribute to understand their implications on basalts chemistry as well as to investigate their interaction with peridotite within an upwelling heterogeneous mantle.

We present the results of partial melting experiments performed on the secondary-type SE pyroxenite Px1 previously studied by Sobolev et al. (2007). The major aim of our work is to depict the composition of melts produced by moderate to high degrees of melting of hybrid pyroxenite at $2 \mathrm{GPa}$. We discuss the fate of these pyroxenitic melts in the context of upwelling heterogeneous mantle as a function of potential temperature of mantle adiabat.

\section{Experimental and analytical techniques}

Px1 is a model olivine-free pyroxenite resulting from the reaction between high-Si eclogite-derived melt and peridotite (Sobolev et al., 2005, 2007). It is a synthetic sintered oxide mixture prepared by blending high purity oxides and carbonates at Australian National University and kindly provided by Gregory Yaxley.

In Fig. 1 the bulk composition of Px 1 is compared with bulk compositions previously used in partial melting experiments at $2 \mathrm{GPa}$ (Table 1). When compared to eclogites and MORB-like pyroxenites (SE pyroxenites), Px1 has significantly higher $X_{\mathrm{Mg}}\left[X_{\mathrm{Mg}}=\right.$ molar $\left.\mathrm{Mg} /\left(\mathrm{Mg}+\mathrm{Fe}^{\mathrm{tot}}\right)=0.81\right]$ and $\mathrm{SiO}_{2}$ content coupled with relatively low $\mathrm{Al}_{2} \mathrm{O}_{3}$ and $\mathrm{CaO}$ contents (Fig. 1). This bulk composition diverges from the nominally "dry" SD pyroxenites in relation to much higher $\mathrm{SiO}_{2}$ content (Fig. 1). Moreover, in spite of similar $X_{\mathrm{Mg}}$, Px1 has higher $\mathrm{SiO}_{2}$ and $\mathrm{Al}_{2} \mathrm{O}_{3}$ and lower $\mathrm{CaO}$ when compared with the clinopyroxenite OLCPX1 experimentally investigated by Kogiso and Hirschmann (2001) (Fig. 1).

Experiments were conducted at $2.0 \mathrm{GPa}$, and temperatures from 1250 to $1480{ }^{\circ} \mathrm{C}$, at the Laboratorio di Petrologia Sperimentale, Dipartimento di Scienze della Terra "Ardito Desio", Università degli Studi di Milano. Experiments were carried out in an end-loaded piston cylinder using MgO-Pyrexsalt assemblies. Run durations range from 36 to $168 \mathrm{~h}$ (Ta- 
Table 1. Bulk compositions experimentally investigated at $2 \mathrm{GPa}$.

\begin{tabular}{|c|c|c|c|c|c|c|c|c|}
\hline & $\begin{array}{r}\mathrm{Px} 1 \\
(1)\end{array}$ & $\begin{array}{r}\text { MIX1G } \\
(2)\end{array}$ & $\begin{array}{l}\text { G2 } \\
\text { (3) }\end{array}$ & $\begin{array}{r}77 \mathrm{SL}-582 \\
(4)\end{array}$ & $\begin{array}{r}\text { OLCPX1 } \\
(5)\end{array}$ & $\begin{array}{r}\text { D95-25 } \\
(6)\end{array}$ & $\begin{array}{r}\text { M5-40 } \\
\text { (7) }\end{array}$ & $\begin{array}{r}\text { M7-16 } \\
(8)\end{array}$ \\
\hline $\mathrm{SiO}_{2}$ & 52.88 & 45.60 & 50.05 & 46.38 & 47.92 & 48.96 & 48.53 & 43.58 \\
\hline $\mathrm{TiO}_{2}$ & 0.64 & 0.90 & 1.97 & 0.63 & 0.47 & 0.76 & 0.52 & 0.75 \\
\hline $\mathrm{Al}_{2} \mathrm{O}_{3}$ & 11.31 & 15.20 & 15.76 & 16.42 & 4.49 & 19.66 & 12.37 & 13.73 \\
\hline $\mathrm{Cr}_{2} \mathrm{O}_{3}$ & 0.25 & 0.11 & 0.00 & 0.14 & 0.00 & 0.00 & 0.12 & 0.07 \\
\hline $\mathrm{FeO}$ & 7.58 & 7.80 & 9.35 & 7.64 & 9.26 & 8.54 & 9.02 & 14.51 \\
\hline $\mathrm{MnO}$ & 0.12 & 0.15 & 0.19 & 0.22 & 0.13 & 0.15 & 0.20 & 0.30 \\
\hline $\mathrm{MgO}$ & 18.55 & 16.67 & 7.90 & 16.48 & 23.38 & 8.69 & 16.64 & 12.52 \\
\hline $\mathrm{CaO}$ & 7.08 & 11.48 & 11.74 & 10.74 & 13.72 & 11.04 & 10.89 & 13.77 \\
\hline $\mathrm{Na}_{2} \mathrm{O}$ & 1.53 & 1.40 & 3.04 & 0.99 & 0.63 & 2.07 & 1.65 & 0.75 \\
\hline $\mathrm{K}_{2} \mathrm{O}$ & 0.06 & 0.04 & 0.03 & 0.09 & 0.00 & 0.05 & 0.06 & 0.03 \\
\hline Tot. & 100.00 & 99.35 & 100.03 & 99.73 & 100.00 & 99.92 & 100.00 & 100.01 \\
\hline$X_{\mathrm{Mg}}$ & 0.81 & 0.79 & 0.60 & 0.79 & 0.82 & 0.64 & 0.77 & 0.61 \\
\hline CIPW* & $0 / 6 / 47 / 9 / 38$ & $2 / 34 / 0 / 18 / 48$ & $0 / 13 / 5 / 25 / 57$ & $0 / 27 / 12 / 11 / 50$ & $0 / 37 / 0 / 47 / 15$ & $4 / 11 / 17 / 9 / 63$ & $0 / 28 / 8 / 22 / 41$ & $0 / 18 / 31 / 27 / 22$ \\
\hline
\end{tabular}

* CIPW norm nepheline-olivine-hypersthene-diopside-feldspars (1) this study; (2) Hirschmann et al. (2003); (3) Pertermann and Hirschmann (2003a); (4) Keshav et al. (2004); (5) Kogiso and Hirschmann (2001); (6) Wang et al. (2010); (7) and (8) Lambart et al. (2013).

ble 2) following previous partial melting experiments (i.e., Kogiso and Hirschmann, 2001; Pertermann and Hirschmann, 2003a, b; Lambart et al., 2009; Borghini et al., 2017).

Platinum capsules (outer diameter 3.0; length 7-8 mm) have been welded after being loaded with an inner graphite capsule containing approximately $20 \mathrm{mg}$ of starting material. Graphite isolated the samples from the Pt capsule to avoid Fe loss (e.g., Kinzler, 1997; Walter, 1998). The graphite-Pt assembly keeps the oxygen fugacity below the graphite-CO vapor buffer (e.g., Ulmer and Luth, 1991; Médard et al., 2008). A layer of vitreous carbon spheres (80-125 $\mu \mathrm{m}$ diameter) at the top of the capsule (less than $20 \% \mathrm{wt} \%$ of the starting material) was used to extract a part of the partial melt (e.g., Pickering-Witter and Johnston, 2000; Wasylenki et al., 2003; Médard et al., 2006). A $0.5 \mathrm{~mm}$ thick hard corundum disk separated the thermocouple tip from the platinum capsule. In order to maintain anhydrous conditions (i) the graphite-Pt assembly loaded with the starting material was dried overnight in an oven at $250^{\circ} \mathrm{C}$ before being rapidly welded shut, and the whole assembly was kept in oven at about $200{ }^{\circ} \mathrm{C}$ for several hours before running the experiments. Temperature was measured by S-type thermocouples and is considered to be accurate to $\pm 5^{\circ} \mathrm{C}$. At an initial pressure of $0.25 \mathrm{GPa}$ the sample was heated to $400^{\circ} \mathrm{C}$ for $10 \mathrm{~min}$ in order to soften the Pyrex; then, pressure was raised to the experimental value before reaching the desired temperature. Runs were terminated by turning off the power. Capsules were enclosed in epoxy, sectioned lengthwise, polished, and carbon-coated.

Run products were carefully characterized by backscattered electron (BSE) images and microanalyses using a JEOL JXA 8200 Superprobe equipped with five wavelengthdispersive spectrometers and one energy-dispersive spectrometer (EDS) at the Dipartimento di Scienze della Terra
"Ardito Desio", Università degli Studi di Milano. X-ray element maps further helped the textural and chemical examination of the experimental charges. Analyses on mineral phases were performed using $1 \mu \mathrm{m}$ beam size and beam conditions of $15 \mathrm{kV}$ and $5 \mathrm{nA}$. Counting time was $30 \mathrm{~s}$ for peak and $10 \mathrm{~s}$ for background. Whenever possible, in order to prevent alkali loss, we analyzed glass using a beam size of $5 \mu \mathrm{m}$, or $2-3 \mu \mathrm{m}$ in experiments with very low melt fractions occurring as thin interstitial films.

\section{Results}

\subsection{Phase assemblages and textures}

Experimental details and run products are summarized in Table 2. At $2 \mathrm{GPa}$ and $1250{ }^{\circ} \mathrm{C}$, pyroxenite $\mathrm{Px} 1$ is at subsolidus and the mineral assemblage is made of orthopyroxene, clinopyroxene, and garnet (Fig. S1a in the Supplement). Orthopyroxene occurs, in all runs, as rounded grains ranging from 5 to $20 \mu \mathrm{m}$ in size. Clinopyroxene is smaller $(2-10 \mu \mathrm{m})$ and generally shows polygonal crystals. Garnet is homogenously dispersed in the charges and forms irregular crystals (up to $50 \mu \mathrm{m}$ ) that include small rounded clinopyroxene and rarely orthopyroxene (Fig. 2). At $1280^{\circ} \mathrm{C}$, the incipient melting is testified by the occurrence of very thin patches of glass interstitial to pyroxenes and garnet (Fig. 2a). Chemical analyses of glass in this low- $T$ experiment are quite difficult, although few data have been collected within the carbon sphere layer at the top of the capsule (Fig. S1b). From 1300 to $1400{ }^{\circ} \mathrm{C}$, the amount of glass progressively increases and glass tends to form larger patches $(5-15 \mu \mathrm{m})$ interstitial to residual minerals and concentrated within the carbon spheres layer (Fig. 2b, c). At $1350^{\circ} \mathrm{C}$, garnet is completely exhausted 
Table 2. Experimental run conditions and products.

\begin{tabular}{lrrrrrrr}
\hline Run & $T\left({ }^{\circ} \mathrm{C}\right)$ & $t(h)$ & \multicolumn{5}{c}{ Phase assemblage and modes (wt \%) } \\
\cline { 3 - 8 } & & & opx & $c p x$ & grt & glass & $R 2^{*}$ \\
\hline Px1-9 & 1250 & 168 & $30.1(4.2)$ & $51.1(4.5)$ & $18.8(2.2)$ & - & 0.8977 \\
Px1-5 & 1280 & 144 & $32.6(1.8)$ & $45.9(1.9)$ & $13.3(1.6)$ & $8.2(2.9)$ & 0.1123 \\
Px1-1 & 1300 & 46 & $34.6(2.2)$ & $38.6(1.7)$ & $7.4(1.5)$ & $19.4(5.6)$ & 0.2343 \\
Px1-4 & 1350 & 47 & $33.7(2.4)$ & $32.5(3.1)$ & - & $33.8(3.2)$ & 0.3654 \\
Px1-3 & 1380 & 140 & $32.8(3.3)$ & $22.1(4.7)$ & - & $45.1(3.6)$ & 0.9345 \\
Px1-2 & 1400 & 36 & $31.7(2.8)$ & $9.2(4.6)$ & - & $59.1(4.1)$ & 0.8226 \\
Px1-7 & 1450 & 46 & $15.3(3.4)$ & - & - & $84.7(5.4)$ & 0.7562 \\
Px1-8 & 1480 & 42 & - & - & - & 100 & 0.8854 \\
\hline
\end{tabular}

* Sum of the squares of residuals for all elements calculated as the sum of the squares of the difference between model and calculated composition. opx, orthopyroxene; cpx, clinopyroxene; grt, garnet. Numbers in parentheses are propagated errors estimated by Monte Carlo simulations statistically treated as in Fumagalli et al. (2009).

and glass coexists with large rounded orthopyroxene (40$50 \mu \mathrm{m})$ and smaller clinopyroxene $(5-10 \mu \mathrm{m})$ (Fig. 2c).

At $1400{ }^{\circ} \mathrm{C}$, residual orthopyroxene and minor clinopyroxene are confined at the bottom of the capsule and glass completely fills the carbon sphere layer (Fig. 2d). At $1450^{\circ} \mathrm{C}$, clinopyroxene disappears and a homogeneous glass coexists with coarse residual orthopyroxene $(20-50 \mu \mathrm{m})$. At $1480^{\circ} \mathrm{C}$, the pyroxenite $\mathrm{Px} 1$ is completely melted and the capsule contains glass and quenched minerals (Fig. S1c in the Supplement).

\subsection{Liquid and mineral compositions}

The compositions of glasses and minerals are reported in Table 3. At increasing temperature, $\mathrm{MgO}$ and $\mathrm{Cr}_{2} \mathrm{O}_{3}$ contents progressively increase and $\mathrm{SiO}_{2}, \mathrm{Na}_{2} \mathrm{O}$ and $\mathrm{TiO}_{2}$ abundances decrease (Fig. 3). At near solidus conditions $\left(1280^{\circ} \mathrm{C}\right)$ glass is very high in $\mathrm{SiO}_{2}\left(\mathrm{SiO}_{2}=59.97 \mathrm{wt} \%\right)$. At increasing temperature, $\mathrm{SiO}_{2}$ progressively decreases until orthopyroxene is the only residual phase at $1450^{\circ} \mathrm{C}$ (Fig. 3). $\mathrm{MgO}$ regularly increases along the whole melting range from 3.97 to $18.94 \mathrm{wt} \%$ (Fig. 3). $\mathrm{FeO}$ content is relatively low at $1280^{\circ} \mathrm{C}$, while starting from $1300^{\circ} \mathrm{C}$ it defines a rather flat trend varying from 6.31 to $7.10 \mathrm{wt} \%$ (Fig. 3). $\mathrm{Al}_{2} \mathrm{O}_{3}$ concentration slightly increases as long as garnet is a melting phase, and it progressively decreases once garnet is exhausted ( $T>$ $1350^{\circ} \mathrm{C}$, Fig. 3). $\mathrm{CaO}$ abundance weakly increases up to $1400^{\circ} \mathrm{C}$, as long as clinopyroxene is involved in the melting reactions, and at it decreases at a higher temperature once clinopyroxene is completely consumed (Fig. 3). $\mathrm{Na}_{2} \mathrm{O}$ and $\mathrm{TiO}_{2}$ behave as incompatible elements rapidly decreasing at increasing temperature, from 3.67 to $1.54 \mathrm{wt} \%$ and from 2.39 to $0.61 \mathrm{wt} \%$, respectively (Fig. 3). $\mathrm{K}_{2} \mathrm{O}$ is very low in agreement with its low concentration in the bulk (Table 1); it reaches $0.21 \mathrm{wt} \%$ in experiment near the solidus and decreases with increasing degree of melting (Table 3 ).

In total alkali vs. $\mathrm{SiO}_{2}$ diagram melts produced by pyroxenite Px1 at 2.0 GPa are andesites, are at the lowest temper- ature investigated $\left(1280^{\circ} \mathrm{C}\right)$, and shift to basaltic andesites $\left(1300-1400^{\circ} \mathrm{C}\right)$ and basalts at very high degree of melting (Fig. 4).

Orthopyroxene has an $X_{\mathrm{Mg}}$ average value of 0.83 at subsolidus conditions and, as expected, records a progressive $X_{\mathrm{Mg}}$ increase with temperature up to 0.90 at $1450{ }^{\circ} \mathrm{C}$ (Table 3, Fig. 5a). $\mathrm{Al}_{2} \mathrm{O}_{3}$ content in orthopyroxene decreases across the solidus from 6.88 to $5.84 \mathrm{wt} \%$; it increases as garnet disappears, at $1350{ }^{\circ} \mathrm{C}$ but decreases again at a higher temperature (Table 3). The $\mathrm{CaO}$ abundance is rather high, as observed in previous pyroxenite melting experiments (e.g., Kogiso et al., 1998; Lambart et al., 2009; Borghini et al., 2017); it starts from $1.07 \mathrm{wt} \%$ at subsolidus and reaches $2.01 \mathrm{wt} \%$ at $1450{ }^{\circ} \mathrm{C}$ (Table 3 ). $\mathrm{TiO}_{2}$ weakly decreases with temperature from 0.36 to $0.21 \mathrm{wt} \%$, and $\mathrm{Cr}_{2} \mathrm{O}_{3}$ contents are always lower than $0.3 \mathrm{wt} \%$ (Table 3 ).

Subsolidus clinopyroxene shows an $X_{\mathrm{Mg}}$ value equal to 0.82 and very high $\mathrm{Na}_{2} \mathrm{O}$ content $\left(\mathrm{Na}_{2} \mathrm{O}=2.32 \mathrm{wt} \%\right)(\mathrm{Ta}-$ ble 3). As the melting degree increases, clinopyroxene displays a gradual $X_{\mathrm{Mg}}$ increase up to 0.88 at $1400^{\circ} \mathrm{C}$ (Fig. 5b) and a $\mathrm{Na}_{2} \mathrm{O}$ decrease down to $0.84 \mathrm{wt} \%$ (Table 3). $\mathrm{Al}_{2} \mathrm{O}_{3}$ content is rather constant and varies from 8.91 to $8.21 \mathrm{wt} \%$ (Table 3). $\mathrm{Cr}_{2} \mathrm{O}_{3}$ ranges from 0.28 and $0.43 \mathrm{wt} \%$ (Table 3). In glass-bearing runs, $\mathrm{TiO}_{2}$ content in clinopyroxene decreases at increasing temperature from 0.88 to $0.36 \mathrm{wt} \%$ (Table 3).

Garnet is characterized by an $X_{\mathrm{Mg}}$ increase from 0.74 in the subsolidus experiment to 0.82 at $1300^{\circ} \mathrm{C}$, the last temperature at which it is stable (Table 3). With increasing temperature, garnet shows an increase of pyrope content coupled to a decrease in almandine molecule. $\mathrm{CaO}$ abundance varies in a narrow range from 5.01 to $5.72 \mathrm{wt} \%$ (Table 3). $\mathrm{TiO}_{2}$ content records the highest value in garnet at subsolidus and decreases with temperature, from 0.97 to $0.31 \mathrm{wt} \%$ (Table 3). $\mathrm{Cr}_{2} \mathrm{O}_{3}$ is low at subsolidus and reaches value of $0.44 \mathrm{wt} \%$ in glass-bearing experiment at $1300^{\circ} \mathrm{C}$ (Table 3). 


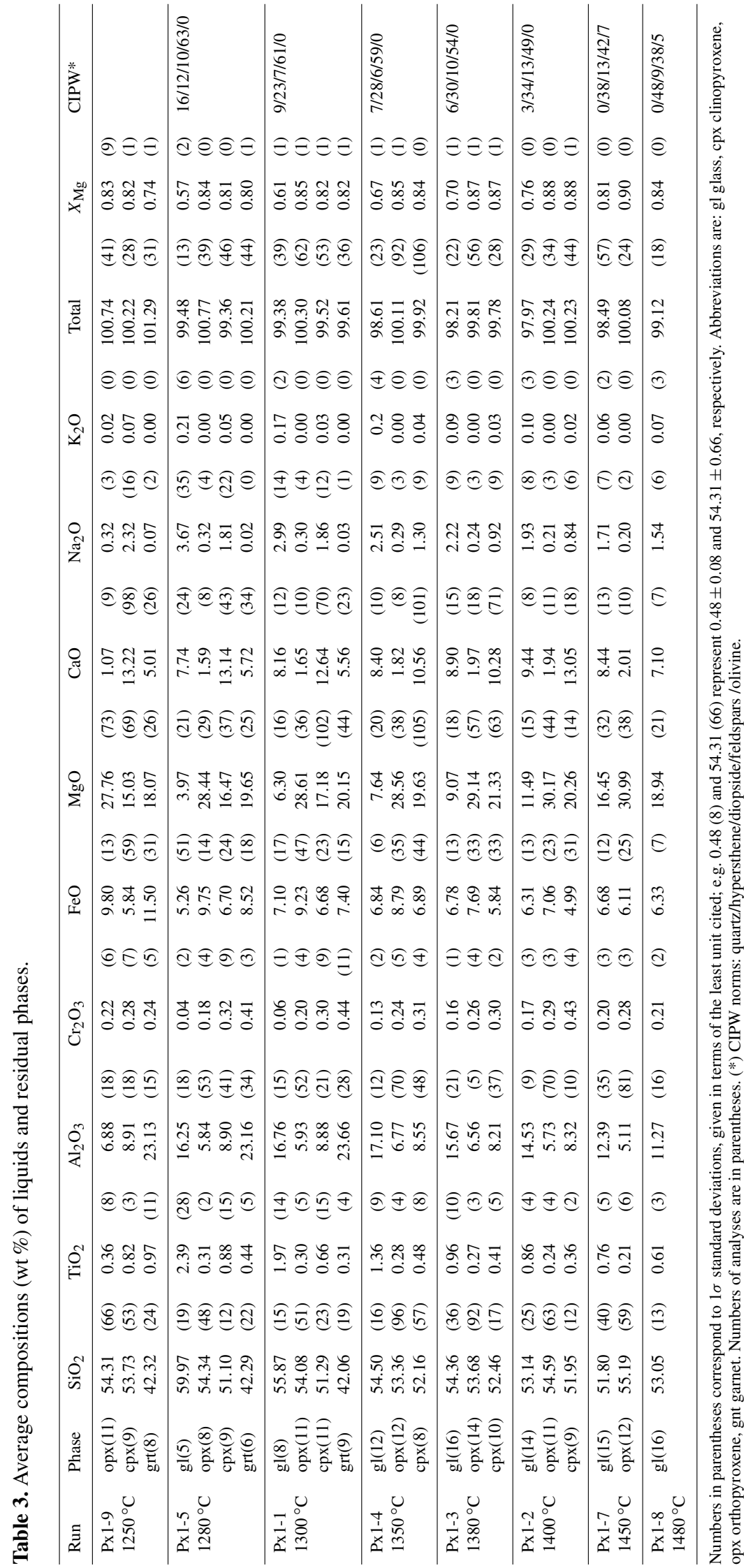



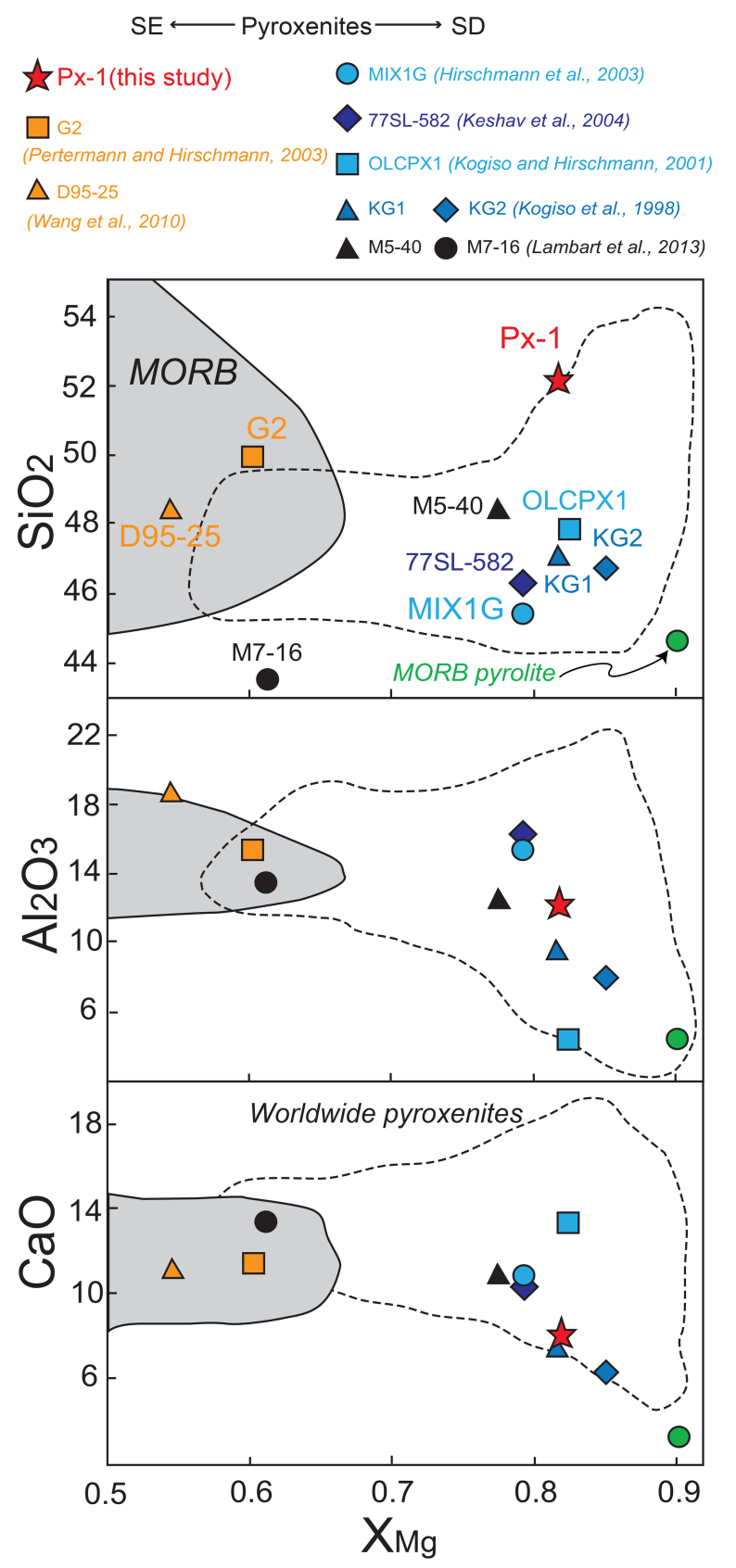

Figure 1. $\mathrm{SiO}_{2}, \mathrm{Al}_{2} \mathrm{O}_{3}$ and $\mathrm{CaO}$ vs. $X_{\mathrm{Mg}}=\mathrm{MgO} /\left(\mathrm{MgO}+\mathrm{FeO}_{\text {tot }}\right)$ diagrams showing the composition from this study (Px1) compared to compositions from previous experimental studies at $2 \mathrm{GPa}$. Silica-excess (SE) pyroxenites (red and orange symbols): olivinefree pyroxenite Px1 (This study); MORB-like pyroxenite G2 (Pertermann and Hisrchmann, 2003a); eclogite D96-25 (Wang et al., 2010). Silica-deficient (SD) pyroxenites (blue and black symbols): garnet pyroxenite MIX1G (Hirschmann et al., 2003); garnet clinopyroxenite 77SL-582 (Keshav et al., 2004); mixtures of peridotite and MORB KG1 (1:1) and KG2 (2: 1) (Kogiso et al., 1998); olivine clinopyroxenite OLCPX1 (Kogiso and Hirschmann, 2001); garnet websterite M5-40 and garnet-olivine clinopyroxenite M7-16 (Lambart et al., 2013). The compositional field defined by MORB (Gale et al., 2013) and the MORB pyrolite (Green et al., 1979) are also reported.
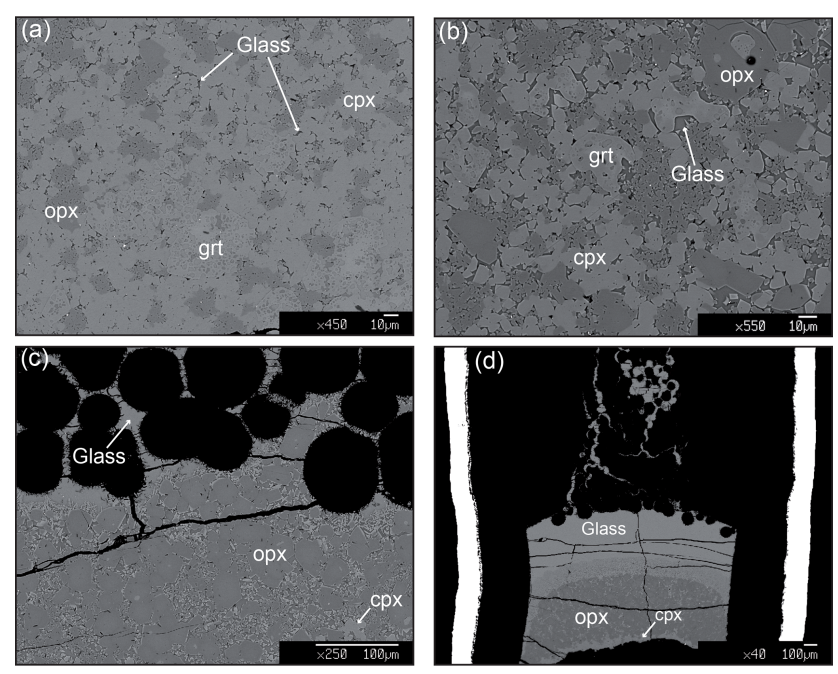

Figure 2. Backscattered electron (BSE) images of representative textures of melting experiments on pyroxenite Px1. (a) Run Px1-5 $\left(1280^{\circ} \mathrm{C}\right)$ : the occurrence of very thin patches of glass interstitial to pyroxene and garnet indicates a very low degree of melting. (b) Run Px1-1 $\left(1300^{\circ} \mathrm{C}\right)$ : glass patches $(5-15 \mu \mathrm{m})$ in equilibrium with residual clinopyroxene, orthopyroxene, and garnet. (c) Run Px1$4\left(1350^{\circ} \mathrm{C}\right)$ : large rounded orthopyroxene $(40-50 \mu \mathrm{m})$ and smaller clinopyroxene $(5-10 \mu \mathrm{m})$ coexisting with liquid mostly contained in the carbon sphere layer. (d) Run Px 1-2 (1400 $\left.{ }^{\circ} \mathrm{C}\right)$ : high-degree melting experiments with residual orthopyroxene and minor clinopyroxene at the bottom of the capsule and glass completely filling the carbon sphere layer.

\subsection{Approach to equilibrium}

Although the present set of experiments was not reversed, some observations strongly suggest that chemical equilibrium was closely approached. X-ray element maps revealed that minerals are compositionally homogeneous and chemically unzoned (Fig. S2). Systematic and consistent variations in mineral chemistry as a function of pressure and temperature conditions also support the attainment of equilibrium, as well as the coherent element partitioning. In particular, the $\mathrm{Fe}-\mathrm{Mg}$ partitioning between clino- and orthopyroxene defined in our experiments is in good agreement with the partitioning computed using the thermobarometer of Brey and Köhler (1990) (Fig. 5c).

Mass balance calculations by a weighted least squares method (Table 2) provided phase abundances consistent with the melt fraction variations. Residual sums of squares lower than 1 are perfectly comparable to other experimental studies (i.e., Kogiso and Hirschmann, 2001; Pertermann and Hirschmann, 2003a, b; Lambart et al., 2009; Borghini et al., 2017) and indicate reasonable mass balances between analyzed phases and the starting bulk composition. Moreover, results of mass balance calculations indicate that $\mathrm{Fe}$ loss was very low $(<3 \%)$ in experiments below $1380^{\circ} \mathrm{C}$, and it increases at a higher temperature up to $8 \%$, possibly due to 

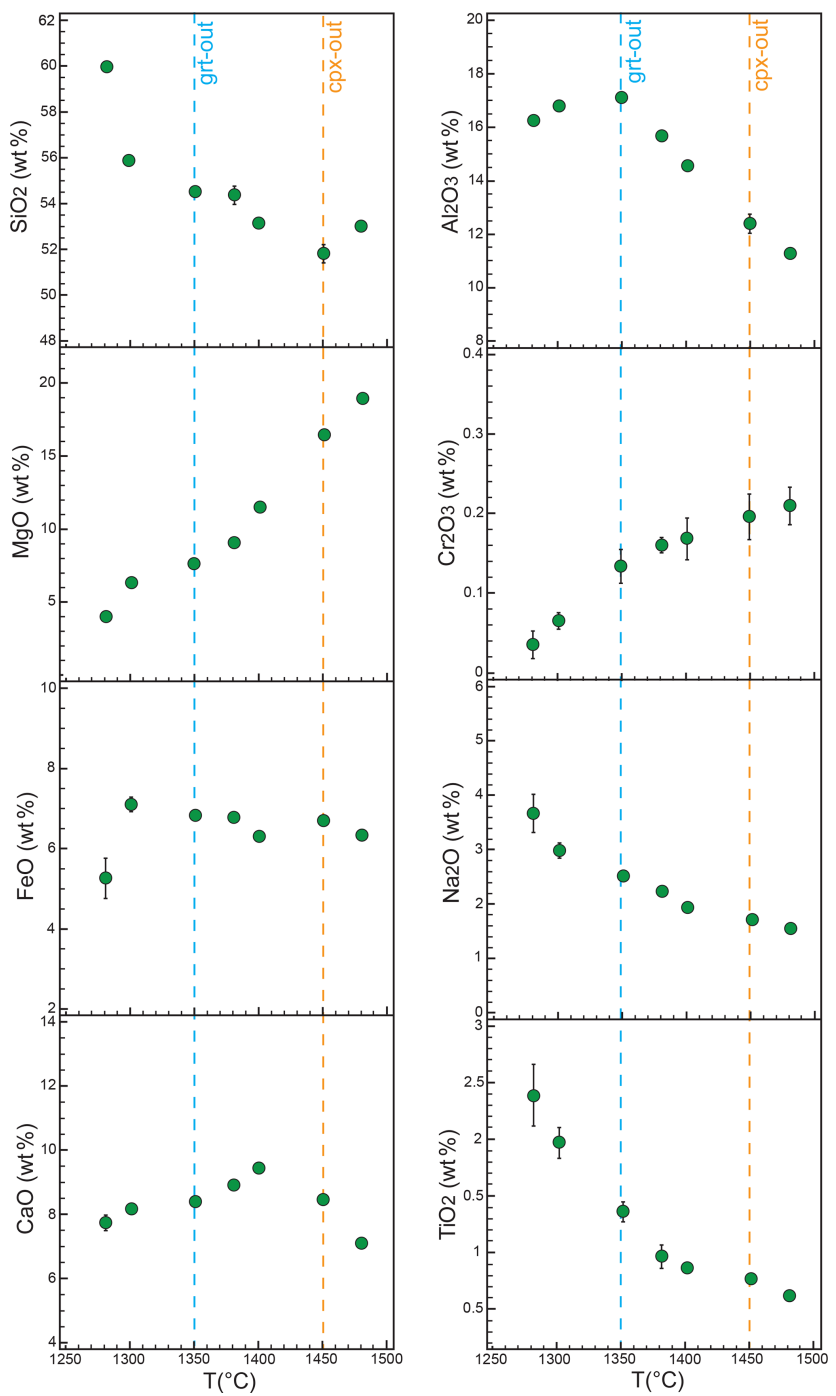

Figure 3. Oxide concentrations (wt \%) in experimental melts vs. temperature $\left({ }^{\circ} \mathrm{C}\right)$. When not visible, the error bar $(1 \sigma)$ is smaller than the symbol. Also reported are the limits of garnet and clinopyroxene stability, the blue and orange dashed lines, respectively.

fractures in graphite inner capsule towards the Pt outer capsule.

\section{Discussion}

\subsection{Melting and phase relations}

Glass and mineral abundances have been calculated by weighted least squares mass balance based on nine oxides: $\mathrm{SiO}_{2}, \mathrm{TiO}_{2}, \mathrm{Al}_{2} \mathrm{O}_{3}, \mathrm{Cr}_{2} \mathrm{O}_{3}, \mathrm{FeO}, \mathrm{MgO}, \mathrm{CaO}, \mathrm{Na}_{2} \mathrm{O}$, and $\mathrm{K}_{2} \mathrm{O}$ (Table 2). Error propagation was carried out by Monte Carlo simulations. Detailed explanation of mass balance calculations is reported in Fumagalli et al. (2009). In Fig. 6 we illustrate the variation of phase abundances as a function of tem-

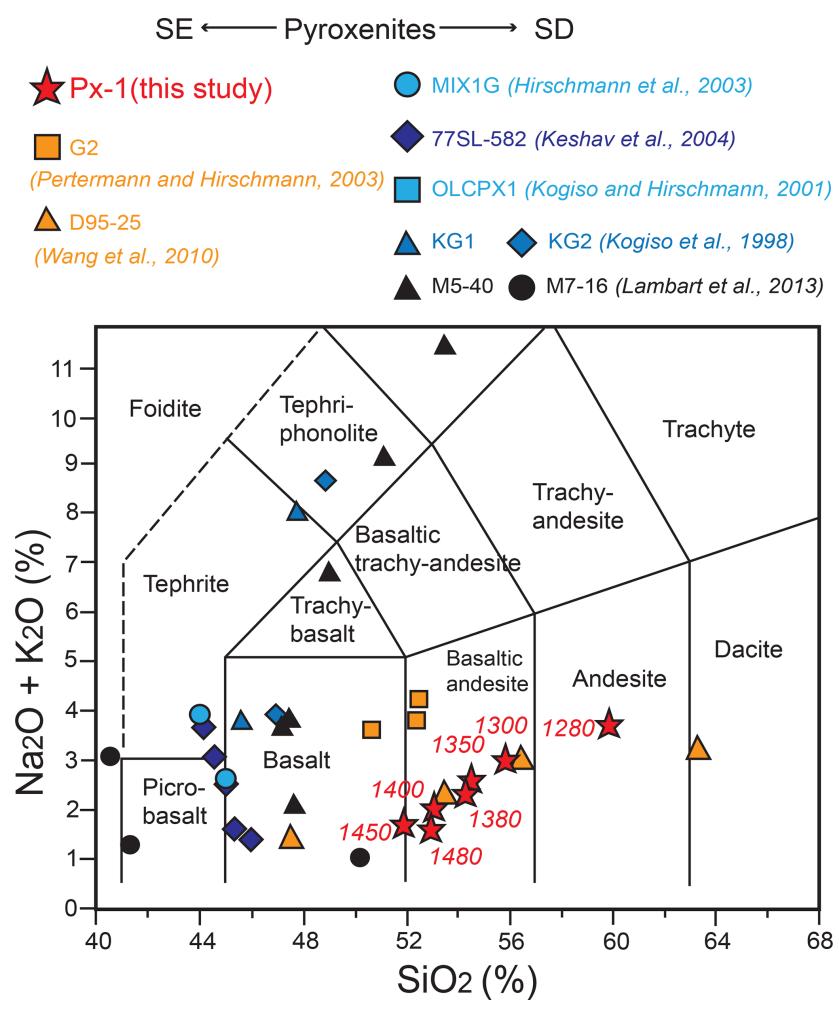

Figure 4. TAS (total alkali vs. silica) diagram showing the composition of Px1 partial melts compared to liquid compositions from different SE and SD pyroxenites experimentally derived at $2 \mathrm{GPa}$. Symbols and references are as in Fig. 1.

perature. At $1250^{\circ} \mathrm{C}$, glass is absent and Px 1 is a garnet websterite formed by clinopyroxene $(51.1 \pm 4.5 \mathrm{wt} \%)$, orthopyroxene $(30.1 \pm 4.2 \mathrm{wt} \%)$, and garnet $(18.8 \pm 2.2 \mathrm{wt} \%)$. Orthopyroxene is stable along the whole melting interval with modal amounts increasing from 30.1 to $34.6 \pm 2.2 \mathrm{wt} \%$, from subsolidus condition up to melt fraction of $19.4 \pm 5.6 \mathrm{wt} \%$ at $1300{ }^{\circ} \mathrm{C}$ (Table 2 and Fig. 6). This indicates that orthopyroxene is a product of melting reaction as long as garnet is present in the residue.

Clinopyroxene is the dominant phase in pyroxenite Px 1 at subsolidus. It is largely consumed by the melting reaction and completely exhausted at $1450^{\circ} \mathrm{C}$ at a melt fraction of $84.7 \pm 4.5 \mathrm{wt} \%$ (Table 2; Fig. 6). Garnet is the first phase to disappear from the residue at a temperature lower than $1350^{\circ} \mathrm{C}$ and a melt fraction lower than $33.8 \pm 3.2 \mathrm{wt} \%$ (Table 2; Fig. 6). With increasing melt fraction, the sequence of mineral phase disappearance is garnet-clinopyroxeneorthopyroxene.

Melting reactions for Px 1 at $2 \mathrm{GPa}$ are derived from mass balance calculations, fitting modal abundances of residual phases vs. melt fractions by least-squares (Baker and Stolper, 1994). In the range of $1250-1300^{\circ} \mathrm{C}$, the partial melting of 

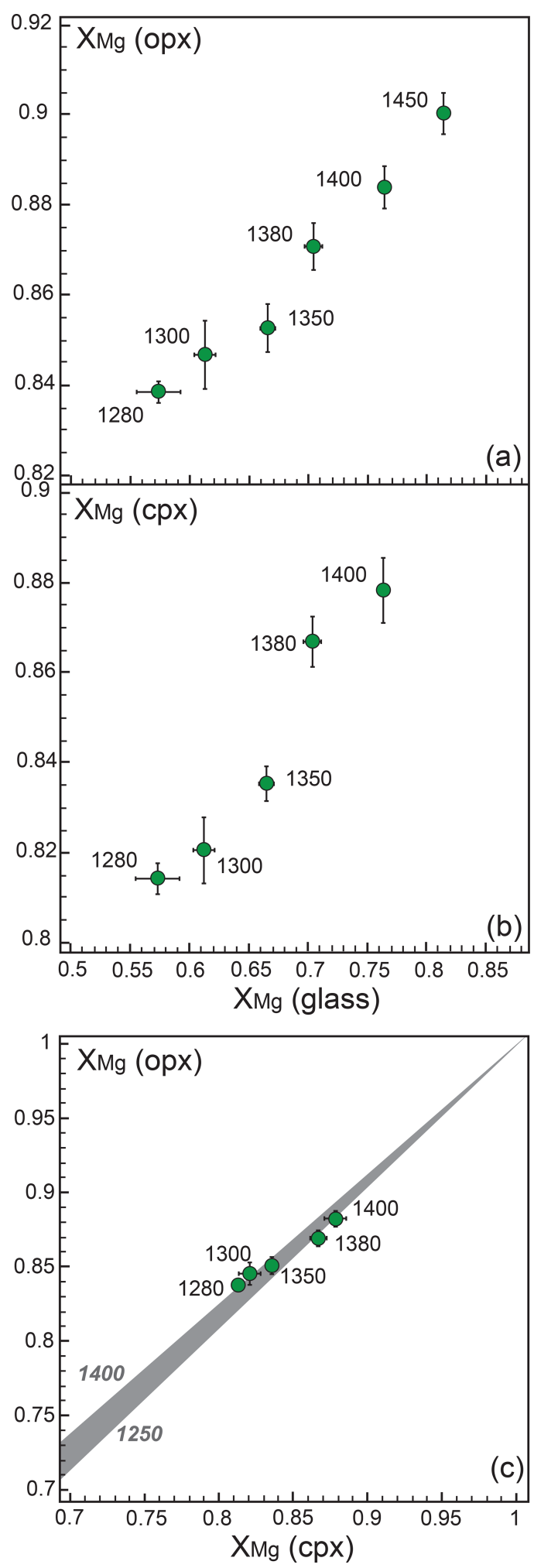

Figure 5. Fe-Mg partitioning between glass and orthopyroxene (a), glass and clinopyroxene (b), and clinopyroxene and orthopyroxene (c). $X_{\mathrm{Mg}}=\mathrm{Mg} /\left(\mathrm{Mg}+\mathrm{Fe}^{\mathrm{tot}}\right)$. In (c) the gray field is defined by curves computed from the clinopyroxene-orthopyroxene thermobarometer of Brey and Köhler (1990) in the temperature range from 1250 to $1400^{\circ} \mathrm{C}$, at a pressure of $2 \mathrm{GPa}$.

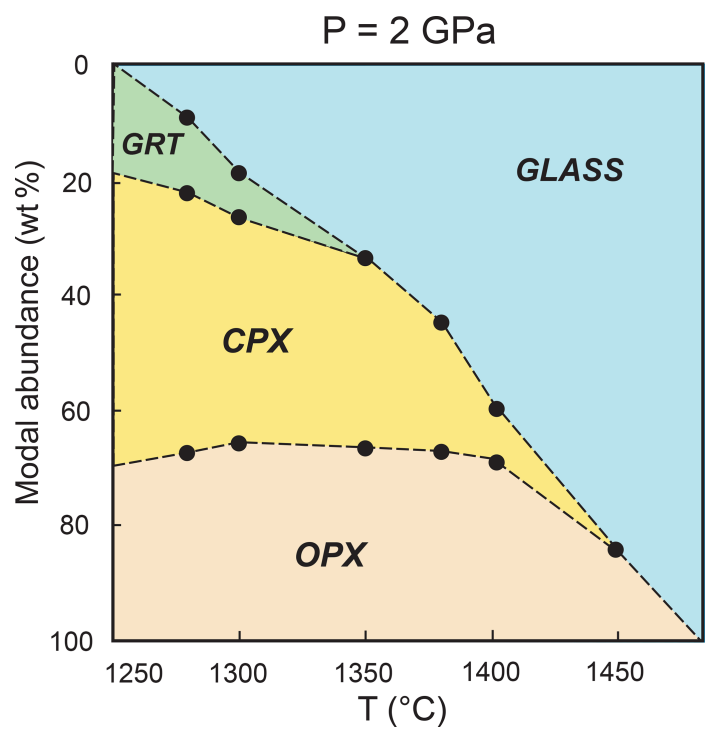

Figure 6. Phase abundances in experimental charges calculated by weighted least squares mass balance as a function of temperature $\left({ }^{\circ} \mathrm{C}\right)$. $C P X$ : clinopyroxene, $O P X$ : orthopyroxene, GRT: garnet.

Px1 is controlled by following reaction:

$$
\begin{aligned}
0.58 \text { garnet }+ & 0.64 \text { clinopyroxene }=1 \text { liquid } \\
+ & 0.22 \text { orthopyroxene. }
\end{aligned}
$$

At $1350^{\circ} \mathrm{C}$ garnet is completely consumed, the orthopyroxene becomes a reactant, and in the range $1350-1400^{\circ} \mathrm{C}$ the melting reaction is

$$
\begin{aligned}
0.92 \text { clinopyroxene } & +0.08 \text { orthopyroxene } \\
= & 1 \text { liquid } .
\end{aligned}
$$

At $1450^{\circ} \mathrm{C}$ clinopyroxene is exhausted; orthopyroxene is the liquidus phase and at $1480^{\circ} \mathrm{C} \mathrm{Px} 1$ is completely molten.

At $2 \mathrm{GPa}$, Px1 melting interval is about $200^{\circ} \mathrm{C}$, which is similar to the melting interval documented for other pyroxenites and eclogites (Pertermann and Hirschmann, 2003b; Keshav et al., 2004). Experiments performed at $P=3.5 \mathrm{GPa}$ (Sobolev et al., 2007) indicated that orthopyroxene is not present in the subsolidus assemblage, presumably due to the higher solubility of enstatite component in clinopyroxene at increasing pressure. However, it represents a product of melting reaction for low degrees of partial melting and it is consumed at high degrees of melting up to the liquidus (Sobolev et al., 2007).

Melting reactions 1 and 2 differ from those observed in olivine-free SD garnet pyroxenites because spinel is stable, with or without garnet, at subsolidus conditions and a low degree of melting (Hirschmann et al., 2003; Keshav et al., 2004). Moreover, in the SD pyroxenites orthopyroxene appears as a product of reaction clinopyroxene + spinel $=$ liquid + orthopyroxene only at a high degree of melting (Keshav et al., 2004). Melting relations experimentally derived 
for SE MORB-like pyroxenite G2 at 3 GPa indicated that garnet and clinopyroxene strongly contribute to melt formation at near solidus, together with rutile and quartz that quickly disappear after very low melting degree (Pertermann and Hirschmann, 2003a). At 2-3 GPa, clinopyroxene is on the liquidus of the SE pyroxenite $\mathrm{G} 2$ and orthopyroxene is never stable either as a subsolidus or as a residual phase (Pertermann and Hirschmann, 2003a, b).

\subsection{Melt productivity at $2 \mathrm{GPa}$}

The solidus of olivine-free pyroxenite Px 1 at $2 \mathrm{GPa}$ is located between 1250 and $1280^{\circ} \mathrm{C}$. In Fig. 7 we show melt fractions of this study, derived by mass balance calculations, as a function of temperature compared with previous partial melting experiments at $2 \mathrm{GPa}$ on other pyroxenites (Kogiso et al., 1998; Hirschmann et al., 2003; Keshav et al., 2004; Lambart et al., 2013), eclogites (Pertermann and Hirschmann, 2003b; Wang et al., 2010), and lherzolites (Hirose and Kushiro, 1993). Experimental data on Px1 and most of all the other compositions show melt fraction vs. temperature relations that are rather straight or weakly concave upwards. As a result we assume a linear isobaric melt productivity $(\mathrm{d} F / \mathrm{d} T)_{\mathrm{P}}$ and quantify it as $(\Delta F / \Delta T)_{\mathrm{P}}=\left[\left(F_{T 2^{-}}\right.\right.$ $\left.\left.F_{T 1}\right) /\left(T_{2}-T_{1}\right)\right]_{\mathrm{P}}$, where $T_{1}$ and $T_{2}$ are minimum and maximum experimental temperature, respectively. Px1 presents a melt fraction vs. temperature trend rather comparable with other pyroxenites and eclogites (Fig. 7). In particular Px1 has a $(\Delta F / \Delta T)_{\mathrm{P}}=0.45$, which is slightly lower than the value of 0.53 determined for basaltic pyroxenite G2 (Pertermann and Hirschmann, 2003b). Furthermore, eclogites display similar isobaric melt productivity but shifted towards lower temperatures than pyroxenites, in agreement with their more fertile compositions in terms of $X_{\mathrm{Mg}}$ and alkali contents (e.g., Kogiso et al., 2004a; Lambart et al., 2016). On the other hand, experiments on garnet pyroxenite at $2 \mathrm{GPa}$ (Keshav et al., 2004) provide a rather high $(\Delta F / \Delta T)_{\mathrm{P}}=0.78$.

Using the empirical parameterization proposed by Lambart et al. (2016), we computed the melt fraction vs. temperature relation for composition Px 1 from $5 \%$ of melting up to clinopyroxene disappearance (red dashed line in Fig. 7). Compared to our experiments, the model gives a slightly steeper isobaric melt productivity, with $(\Delta F / \Delta T)_{\mathrm{P}}=0.56$. At fixed melt fraction, the slightly higher temperatures of the model, as compared with the experimentally derived melt fraction vs. temperature relation, are within the standard error of the parameterization $\left( \pm 30^{\circ}\right.$, Lambart et al., 2016).

In comparison, melt fractions obtained in experiments on lherzolites yield lower values of $(\mathrm{d} F / \mathrm{d} T)_{\mathrm{P}}$ (Fig. 7). In the range $1375-1400^{\circ} \mathrm{C}$, pyroxenite $\mathrm{Px} 1$ produces a melt amount that is more than 3 times the amount potentially extracted from the fertile lherzolite KLB-1. In keeping with the steeper $(\mathrm{d} F / \mathrm{d} T)_{\mathrm{P}}$ of pyroxenite, the difference in isobaric melt production between Px1 and peridotite increases with temperature (Fig. 7).
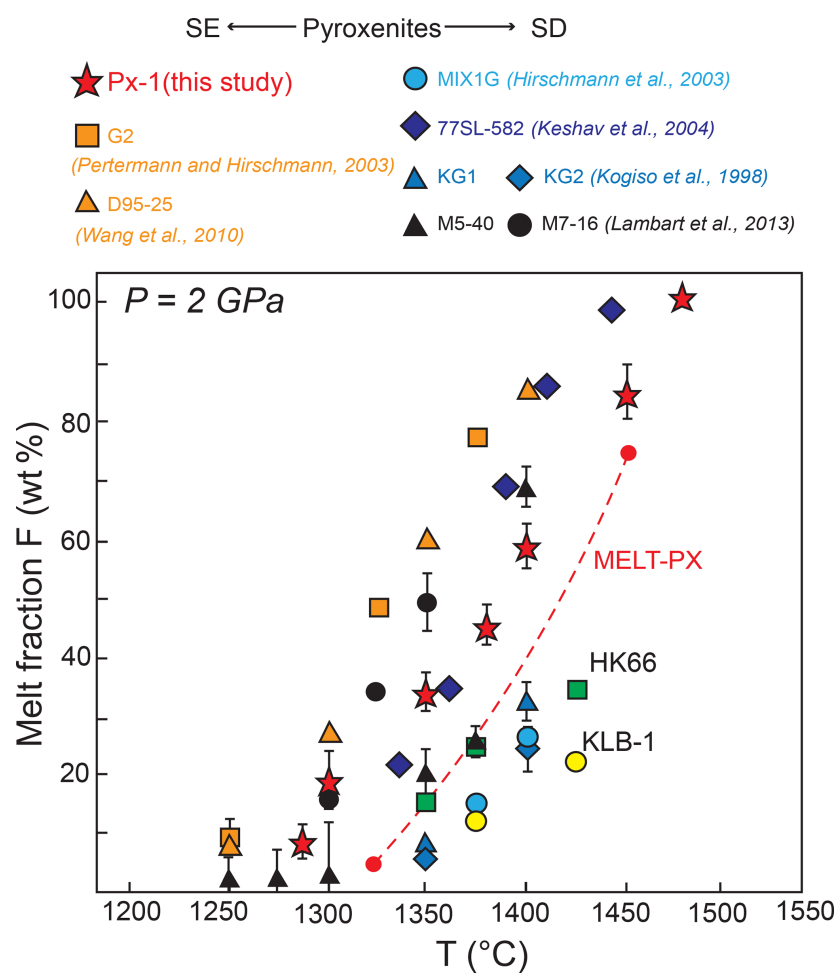

Figure 7. Temperature vs. melt fraction determined for pyroxenite Px1 (this work) compared to those from other experimental studies on dry SE and SD pyroxenites, eclogites, and peridotites at $2 \mathrm{GPa}$. Symbols and references are as in Fig. 1. Melt fractions of a highly fertile lherzolite (HK66) and fertile lherzolite (KLB-1) experimentally derived at 2 GPa (Hirose and Kushiro, 1993) are also shown for comparison. "MELT-PX" refers to the melt fraction curve (from $5 \%$ melting up to clinopyroxene disappearance) computed for composition Px1 using the parameterization proposed by Lambart et al. (2016).

\subsection{Composition of pyroxenite-derived melts at $2 \mathrm{GPa}$ and their role in upwelling mantle}

In Fig. 8, the compositions of melts produced by pyroxenite Px1 are projected from diopside (Di) in the pseudo-ternary diagram Fo-CaTs-Qz and compared with the compositions of partial melts obtained in melting experiments on peridotites and pyroxenites at $2 \mathrm{GPa}$. All the compositions of Px 1 partial melts, as well as the Px1 bulk, plot on the right side of the CaTs-En join, together with the other SE MORBpyroxenites G2 (Pertermann and Hirschmann, 2003a) and D95-25 (Wang et al., 2010). In agreement with the presence of the thermal divide at $2 \mathrm{GPa}$ (e.g., Kogiso et al., 2004a; Lambart et al., 2013), the SD pyroxenites and peridotites produce melt compositions plotting on the left side of the CaTs-En join (Fig. 8). In order to evaluate the effect of pressure, the partial melts reported for the same bulk composition Px1 at 3.5 GPa (Sobolev et al., 2007) are considered. Although up to moderate melting degree melt compositions at $3.5 \mathrm{GPa}$ are well comparable with those at $2 \mathrm{GPa}$, at in- 


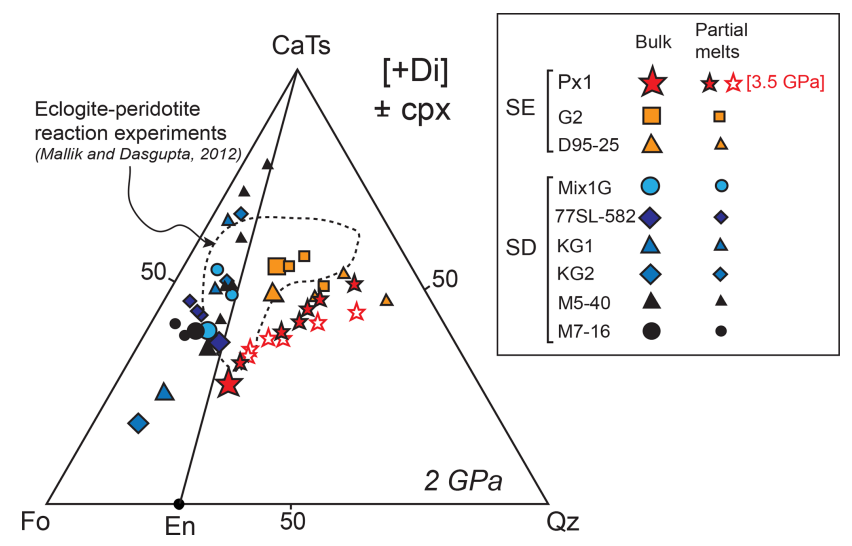

Figure 8. Molar projections from diopside [Di] into the pseudoternary diagram forsterite-Ca-Tschermak-quartz (Fo-CaTs-Qz) (O'Hara, 1972) of melts produced by experiments on Px1 at $2 \mathrm{GPa}$ (this study) and 3.5 GPa (Sobolev et al., 2007). The melt compositions reported in previous experimental studies on other pyroxenites, eclogites, and peridotites are also plotted. Symbols and references are as in Fig. 7. Larger symbols represent the starting bulk compositions.

creasing melt fractions they deviate towards the quartz apex (Fig. 8). This is presumably related to the fact that, at high pressure $(3.5 \mathrm{GPa})$, orthopyroxene is not involved in melting reactions until high degrees of melting are reached (Sobolev et al., 2007).

In Fig. 9 the compositions of partial melts derived from Px1 are compared with experimental results for different pyroxenites, eclogites, and peridotites at $2 \mathrm{GPa}$. Although major element oxides $\left(\mathrm{Al}_{2} \mathrm{O}_{3}, \mathrm{Na}_{2} \mathrm{O}, \mathrm{TiO}_{2}\right.$ and $\mathrm{Cr}_{2} \mathrm{O}_{3}$, Fig. 9) present very similar abundances in all bulk compositions, partial melts of Px1 show higher $\mathrm{SiO}_{2}$ and slightly lower $\mathrm{CaO}$. Interestingly, the Px1 partial melts, although very similar to eclogitic melts (Pertermann and Hirschmann, 2003a; Wang et al., 2010), present significantly higher $X_{\mathrm{Mg}}$ values. At $2 \mathrm{GPa}$, liquids produced by eclogites display $X_{\mathrm{Mg}}$ lower than 0.60, whereas Px1 melts vary within a range of higher $X_{\mathrm{Mg}}$ value $\left(X_{\mathrm{Mg}}=0.57-0.81\right)$ (Fig. 9). On the other hand, for moderate to high degree of melting, Px1 partial melts have $X_{\mathrm{Mg}}$ similar to peridotite-derived melts but with higher $\mathrm{SiO}_{2}$ contents (Fig. 9).

In order to discuss the implications of melting of olivinefree hybrid pyroxenite Px1, we simulated the evolution of an upwelling heterogeneous mantle at $2 \mathrm{GPa}$, using the parameterization of Lambart et al. (2016). The model allows one to distinguish the contribution of melting of pyroxenite Px1 and fertile lherzolite during the decompressional evolution of a mixed pyroxenite-peridotite mantle source, taking into account the thermodynamics of heterogeneous veined mantle (Phipps Morgan, 2001). We assumed potential temperatures from 1300 to $1550^{\circ} \mathrm{C}$, which represent the potential temperatures for ambient mantle below oceanic ridges and plume settings (e.g., Herzberg et al., 2007). We consid-
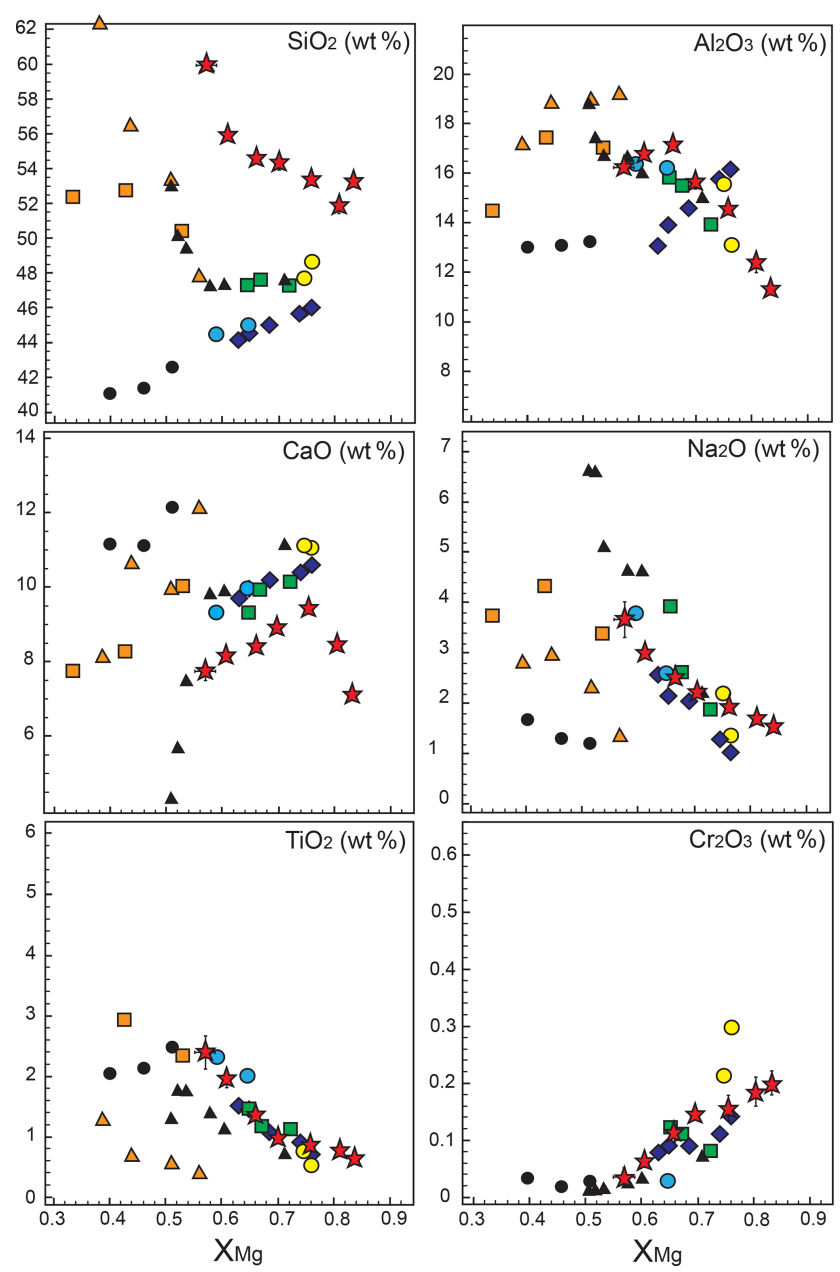

Figure 9. Compositions (wt \%) of Px1 partial melts from this study compared with those of experimental melts in SE and SD pyroxenites, eclogites, and peridotites at $2.0 \mathrm{GPa}$. Symbols and references are as in Fig. 7.

ered heterogeneous mantle portions made of fertile lherzolite hosting pyroxenite $\mathrm{Px} 1$ in different mass fraction, i.e., 0.05 , 0.02 and 0.5 .

Although geochemical and physical models point to pyroxenite abundance in an upwelling mantle at oceanic ridge and plume settings mostly limited to $4 \%-10 \%$, and rarely up to $20 \%$ (e.g., Hirschmann and Stolper, 1996; Pertermann and Hirschmann, 2003b; Lambart et al., 2009; Shorttle and Maclennan, 2011; Shorttle et al., 2014; Brown and Lesher, 2014; Lambart, 2017), secondary-type pyroxenites (as Px1) could be locally more abundant in the mantle. This is because the reaction between eclogite-derived melt and peridotite is able to readily produce a large volume of orthopyroxenebearing lithologies at the expense of peridotite (Wang et al., 2019). Pyroxenite-rich mantle outcrops documented in orogenic (e.g., Gysi et al., 2011; Hidas et al., 2013) and ophiolitic massifs (e.g., Borghini et al., 2013, 2016; Basch et al., 2019) support this view. However, hybrid rocks have major 
element composition more refractory with respect to eclogites, often assumed as proxies of the enriched mantle components. Therefore, the geochemical signature that secondary type pyroxenites could transfer to aggregated melts is more diluted (Lambart et al., 2009; Borghini et al., 2017), and the difference in density with the ambient peridotite is significantly reduced (e.g., Schutt and Lesher, 2006).

For a mantle adiabat with a potential temperatures of $1350-1550^{\circ} \mathrm{C}$, at $2 \mathrm{GPa}$ both lherzolite and pyroxenite Px 1 encounter partial melting. Calculations indicate that pyroxenite Px1 is able to produce melt fractions up to 4 times those produced by the associate lherzolite (Fig. S3). However, in spite of a much higher melt productivity, assuming a pyroxenite mass fraction of $5 \%$, Px 1 modestly contributes to the whole melt fraction. On the contrary, for mantle source containing $50 \%$ of Px1, the contribution to the melt production coming from the pyroxenite component increases up to about $80 \%$ of the whole liquid (Fig. S3). According to the chemical data summarized in Fig. 9, the composition of melts produced by such heterogeneous sources should be basalts with higher $\mathrm{SiO}_{2}$ and slightly lower $\mathrm{CaO}$ contents than partial melt produced by peridotite at the same $P-T$ conditions.

We computed the activity of $\mathrm{SiO}_{2}\left(a_{\mathrm{SiO} 2}\right)$ of partial melts from Px1 and KLB-1 using MELTS supplemental calculator (Ghiorso and Sack, 1995; Asimow and Ghiorso, 1998) in order to make inferences on the fate of these aggregated melts at lithospheric mantle depths. Px1 partial melts are quartz- or hypersthene-normative liquids (Table 3) with high $a_{\mathrm{SiO} 2}$ that decreases from 0.59 to 0.44 as the melting degree increases. At similar conditions, lherzolite KLB-1 produces melt with $a_{\mathrm{SiO} 2}$ of 0.37 and 0.41 at 1375 and $1425^{\circ} \mathrm{C}$, respectively. Lambart et al. (2012) have investigated the reaction between pyroxenite-derived melt and peridotite by impregnation experiments at 1 and $1.5 \mathrm{GPa}$ combined with thermodynamic calculations. They argued that such interaction results in clinopyroxene-rich product coexisting with olivine or orthopyroxene as a function of $a_{\mathrm{SiO} 2}$ of reacting melts. Using impregnating melts with a rather high $a_{\mathrm{SiO} 2}$ (e.g., 0.44), they found that melt-peridotite reaction results in olivine dissolution and orthopyroxene crystallization.

We expect therefore that aggregated melts produced by Px1-lherzolite source should inherit high $\mathrm{SiO}_{2}$ activities, even if Px1 moderately contributes to melt production of the whole mantle source. In spite of their relatively high $X_{\mathrm{Mg}}$, making them rather similar to peridotite-derived melts (Fig. 9), they are expected to be reactive with ambient mantle peridotite. This could likely imply that they cannot be extracted from the mantle without a significant chemical modification via melt-peridotite reaction that would prevent the transfer of their geochemical signature even in terms of trace elements. According to their high $\mathrm{SiO}_{2}$ activity, the infiltration within shallower mantle peridotite of mixed melts produced by a Px1-bearing mantle source would lead to meltrock reaction and melt consumption by crystallization with the formation of websteritic rocks (Lambart et al., 2012).
However, the capability of pyroxenite-derived melt to directly participate to basalt production depends not only on chemical features but also on physical parameters, such as the length scale of pyroxenite (e.g., Kogiso et al., 2004b; Liu and Liang, 2017) and the porosity (i.e., degree of melting) of the surrounding peridotite (Lambart et al., 2012). Indeed, a large volume of pyroxenite and high porosity of the melting peridotite would favor extraction of these melts. However, the extent to which these parameters allow melt extraction from such heterogeneous mantle source is poorly constrained and still under debate.

For mantle adiabat with a potential temperature lower than $1350{ }^{\circ} \mathrm{C}$, according to the model results, mantle peridotite is subsolidus or in a state of incipient melting $(F<2 \%)$. Our experiments indicate that pyroxenite Px1 starts melting between 1250 and $1280^{\circ} \mathrm{C}$ with melt fraction increasing rapidly with temperature (Fig. 6). Partial melts derived from Px1 at $T<1350{ }^{\circ} \mathrm{C}$ have very high silica contents $\left(\mathrm{SiO}_{2}=55-59 \mathrm{wt} \%\right)$ and silica activity $\left(a_{\mathrm{SiO} 2}=0.52-0.59\right)$; therefore, they are expected to react with subsolidus mantle peridotite to produce orthopyroxene-rich lithologies (e.g., Yaxley and Green, 1998; Lambart et al., 2012). Mallik and Dasgupta (2012) experimentally demonstrated that the melts resulting from the interaction between MORB-eclogite partial melts and subsolidus peridotite follow similar chemical evolution of OIBs and some MORBs, from tholeiitic to alkalic melts (Michael et al., 2003; Standish et al., 2008). Partial melts of Px1 are closer to the thermal divide than the eclogitic melts considered by Mallik and Dasgupta (2012), suggesting that a similar geochemical evolution is expected, even for minor melt-rock interaction. However, the reaction between subsolidus peridotite and silica-rich melts likely leads to local freezing (e.g., Lambart et al., 2012; Rosenthal et al., 2014) that prevents direct extraction of these melts. Partial melting of olivine-free pyroxenite embedded into subsolidus peridotite would produce an orthopyroxene-rich reaction zone and residual websterites.

The results of this study strongly support the hypothesis that hybrid mantle heterogeneities such as Px1 may contribute to refertilization of the Earth's mantle. Starting from a deep peridotite-dominated mantle enclosing eclogites or pyroxenites, mantle refertilization results from a complex series of processes (e.g., Spandler et al., 2008; Rosenthal et al., 2018). Mantle heterogeneities undergo dynamic and polybaric transformation mostly driven by multiple episodes of partial melting and interactions with the surrounding mantle.

Data availability. All data derived from this research are presented in the enclosed tables and figures.

Supplement. The supplement related to this article is available online at: https://doi.org/10.5194/ejm-32-251-2020-supplement. 
Author contributions. All authors contributed to the experimental strategy, result interpretations, and manuscript preparation.

Competing interests. The authors declare that they have no conflict of interest.

Acknowledgements. The authors are greatly thankful to Gregory Yaxley for providing the starting material Px1. Andrea Risplendente is thanked for technical assistance during the work at the electron microprobe.

Financial support. The research has been supported by the Italian Ministry of Education, University and Research (MIUR) (grant no. PRIN-2015C5LN35) through the project "Melt rock reaction and melt migration in the MORB mantle through combined natural and experimental studies".

Review statement. This paper was edited by Didier Laporte and reviewed by Gordana Garapic and one anonymous referee.

\section{References}

Allègre, C. J. and Turcotte, D. L.: Implications of a two-component marble-cake mantle, Nature, 323, 123-127, 1986.

Asimow, P. D. and Ghiorso, M. S.: Algorithmic modifications extending MELTS to calculate subsolidus phase relations, Am. Mineral., 83, 1127-1132, 1998.

Baker, M. B. and Stolper, E. M.: Determining the composition of high-pressure mantle melts using diamond aggregates, Geochim. Cosmochim. Acta, 58, 2811-2827, 1994.

Basch, V., Rampone, E., Borghini, G., Ferrando, C., and Zanetti, A.: Origin of pyroxenites in the oceanic mantle and their implications on the reactive percolation of the depleted melts, Contrib. Mineral. Petrol., 174, 97, 2019.

Bodinier, J.-L., Garrido, C. J., Chanefo, I., Bruguier, O., and Gervilla, F.: Origin of pyroxenite-peridotite veined mantle by refertilization reactions: Evidence from the Ronda peridotite (Southern Spain), J. Petrol., 49, 999-1025, 2008.

Borghini, G., Rampone, E., Zanetti, A., Class, C., Cipriani, A., Hofmann, A. W., and Goldstein, S. L.: Meter-scale Nd isotopic heterogeneity in pyroxenite-bearing Ligurian peridotites encompasses global-scale upper mantle variability, Geology, 41, 10551058, 2013.

Borghini, G., Rampone, E., Zanetti, A., Class, C., Cipriani, A., Hofmann, A. W., and Goldstein, S. L.: Pyroxenite layersin the Northern Apennines upper mantle (Italy) - Generation by pyroxenite melting and melt infiltration, J. Petrol., 57, 625-653, 2016.

Borghini, G., Fumagalli, P., and Rampone, E.: Partial melting experiments on a natural pyroxenite at 1 and $1.5 \mathrm{GPa}$ : insights on the role of secondary pyroxenites in basalts generation, Contrib. Mineral. Petrol., 172, 70, 2017.

Borghini, G., Rampone, E., Zanetti, A., Class, C., Fumagalli, P., and Godard, M.: Ligurian pyroxenite-peridotite sequences (Italy) and the role of melt-rock reaction in creating enriched-MORB mantle source, Chem. Geol., 532, 119252, 2019.

Brey, G. P. and Köhler, T.: Geothermobarometry in four-phase lherzolites II. New thermobarometers, and practical assessment of existing thermobarometers, J. Petrol., 31, 1353-1378, 1990.

Brown, E. L. and Lesher, C. E.: North Atlantic magmatism controlled by temperature, mantel composition and buoyancy, Nat. Geosci., 7, 820-824, 2014.

Brunelli, D., Cipriani, A., and Bonatti, E.: Thermal effects of pyroxenites on mantle melting below mid-ocean ridges, Nat. Geosci., 11, 520-525, 2018.

Fumagalli, P., Zanchetta, S., and Poli, S.: Alkali in phlogopite and amphibole and their effects on phase relations in metasomatized peridotites: a high-pressure study, Contrib. Mineral. Petrol., 158, 723-737, 2009.

Gale, A., Dalton, C. A., Langmuir, C. H., Su, Y., and Schilling, J.-G.: The mean composition of ocean ridge basalts, Geochem. Geophys. Geosyst., 14, 489-518, 2013.

Garrido, C. J. and Bodinier, J.-L.: Diversity of mafic rocks in the Ronda peridotite: evidence for pervasive melt-rock reaction during heating of subcontinental lithosphere by upwelling asthenosphere, J. Petrol., 40, 729-754, 1999.

Ghiorso, M. S. and Sack, R. O.: Chemical mass transfer in magmatic processes IV. A revised and internally consistent thermodynamic model for the interpolation and extrapolation of liquidsolid equilibria in magmatic systems at elevated temperatures and pressures, Contrib. Mineral. Petrol., 119, 197-212, 1995.

Green, D. H., Hibberson, W. O., and Jaques, A. L.: Petrogenesis of mid ocean ridge basalt, in: The Earth: its Origin, Structure and Evolution, edited by: McElhinney, M. W., Academic Press, London, 265-299, 1979.

Gysi, A. P., Jagoutz, O., Schmidt, M. W., and Targuisti, K.: Petrogenesis of pyroxenites and melt infiltrations in the ultramafic complex of Beni Boussera, Northern Morocco, J. Petrol., 52, 16761735, 2011.

Herzberg, C.: Petrology and thermal structure of the Hawaiian plume from Mauna Kea volcano, Nature, 444, 605-609, 2006.

Herzberg, C.: Identification of source lithology in the Hawaiian and Canary Islands: implications for origins, J. Petrol., 52, 113-146, 2011.

Herzberg, C., Asimow, P. D., Arndt, N., Niu, Y. L., Lesher, C. M., Fitton, J. G., Cheadle, M. J., and Saunders, A. D.: Temperatures in ambient mantle and plumes: Constraints from basalts, picrites, and komatiites, Geochem. Geophys. Geosyst., 8, Q02006, https://doi.org/10.1029/2006GC001390, 2007.

Hidas, K., Garrido, C., Tommasi, A., Padron-Navarta, J.A., Thielmann, M., Konc, Z., Frets, E., and Marchesi, C.: Strain localization in pyroxenite by reaction-enhanced softening in the shallow subcontinental lithospheric mantle, J. Petrol., 54, 1997-2031, 2013.

Hirose, K. and Kushiro, I.: Partial melting of dry peridotites at high pressures: determination of compositions of melts segregated from peridotite using aggregates of diamond, Earth Planet. Sci. Lett., 114, 477-489, 1993.

Hirschmann, M. M. and Stolper, E. M.: A possible role for garnet pyroxenite in the origin of the "garnet signature" in MORB, Contrib. Mineral. Petrol., 124, 185-208, 1996. 
Hirschmann, M. M., Kogiso, T., Baker, M. B., and Stolper, E. M.: Alkalic magmas generated by partial melting of garnet pyroxenite, Geology, 31, 481-484, 2003.

Hofmann, A. W.: Mantle geochemistry; the message from oceanic volcanism, Nature, 385, 219-229, 1997.

Hofmann, A. W.: Sampling mantle heterogeneity through oceanic basalts: isotopes and trace elements, in: Treatise on Geochemistry, the mantle and core, edited by: Carlson, R. W., Holland, H. D., and Turekian, K. K., Elsevier, Oxford, 61-101, 2007.

Keshav, S., Gudfinnsson, G. H., Sen, G., and Fei, Y.: High-pressure melting experiments on garnet clinopyroxenite and the alkalic to tholeiitic transition in ocean-island basalts, Earth Planet. Sci. Lett., 223, 365-379, 2004.

Kinzler, R. J.: Melting of mantle peridotite at pressures approaching the spinel to garnet transition: Application to mid-ocean ridge basalt petrogenesis, J. Geophys. Res., 102, 853-874, 1997.

Kogiso, T. and Hirschmann, M. M.: Experimental study of clinopyroxenite partial melting and the origin of ultra-calcic melt inclusions, Contrib. Mineral. Petrol., 142, 347-360, 2001.

Kogiso, T. and Hirschmann, M. M.: Partial melting experiments of bimineralic eclogite and the role of recycled mafic oceanic crust in the genesis of ocean island basalts, Earth Planet. Sci. Lett., 249, 188-199, 2006.

Kogiso, T., Hirose, K., and Takahashi, E.: Melting experiments on homogeneous mixtures of peridotite and basalt: application to the genesis of ocean island basalts, Earth Planet. Sci. Lett., 162, 45-61, 1998.

Kogiso, T., Hirschmann, M. M., and Frost, D. J.: High pressure partial melting of garnet pyroxenite: possible mafic lithologies in the source of ocean island basalts, Earth Planet. Sci. Lett., 216, 603-617, 2003.

Kogiso, T., Hirschmann, M. M., and Pertermann, M.: High-pressure partial melting of mafic lithologies in the mantle, J. Petrol., 45, 2407-2422, 2004a.

Kogiso, T., Hirschmann M. M., and Reiners, W.: Length scales of mantle heterogeneities and their relationship to ocean island basalt geochemistry, Geochim. Cosmochim. Acta, 68, 345-360, 2004b.

Lambart, S.: No direct contribution of recycled crust in Icelandic basalts, Geochem. Perspect. Lett., 4, 7-12, 2017.

Lambart, S., Laporte, D., and Schiano, P.: An experimental study of pyroxenite partial melts at 1 and $1.5 \mathrm{GPa}$ : implications for the major-element composition of mid-ocean ridge basalts, Earth Planet. Sci. Lett., 288, 335-347, 2009.

Lambart, S., Laporte, D., Provost, A., and Schiano, P.: Fate of pyroxenite-derived melts in the peridotitic mantle: thermodynamic and experimental constraints, J. Petrol., 53, 451-476, 2012

Lambart, S., Laporte, D., and Schiano, P.: Markers of the pyroxenite contribution in the major-element compositions of oceanic basalts: Review of the experimental constraints, Lithos, 160-161, 14-36, 2013.

Lambart, S., Baker, M. B., and Stolper, E. M.: The role of pyroxenite in basalt genesis: Melt-PX, a melting parameterization for mantle pyroxenites between 0.9 and $5 \mathrm{GPa}$, J. Geophys. Res., 121, 5708-5735, 2016.

Lassiter, J. C., Hauri, E. H., Reiners, P. W., and Garcia, M. O.: Generation of Hawaiian post-erosional lavas by melting of a mixed lherzolite/pyroxenite source, Earth Planet. Sci. Lett., 178, 269$284,2000$.

Liu, B. and Liang, Y.: The prevalence of kilometer-scale heterogeneity in the source region of MORB upper mantle, Sci. Adv., 3, e1701872, https://doi.org/10.1126/sciadv.1701872, 2017.

Mallik, A. and Dasgupta, R.: Reaction between MORB-eclogite derived melts and fertile peridotite and generation of ocean island basalts, Earth Planet. Sci. Lett., 329-330, 97-108, 2012.

Mallik, A. and Dasgupta, R.: Reactive infiltration of MORBeclogite-derived carbonated silicate melt into fertile peridotite at $3 \mathrm{GPa}$ and genesis of alkali magmas, J. Petrol., 54, 2267-2300, 2013.

Mallik, A. and Dasgupta, R.: Effect of variable $\mathrm{CO}_{2}$ on eclogitederived andesite and lherzolite reaction at $3 \mathrm{GPa}$ - Implications for mantle source characteristics of alkali ocean island basalts, Geochem. Geophys. Geosyst., 15, 1533-1557, 2014.

Marchesi, C., Garrido, C. J., Bosch, D., Bodinier, J.-L., Gervilla, F., and Hidas, K.: Mantle refertilization by melts of crustal-derived garnet pyroxenite: Evidence from the Ronda peridotite massif, southern Spain, Earth Planet. Sci. Lett., 362, 66-75, 2013.

Médard, E., Schmidt, M. W., Schiano, P., and Ottolini, L.: Melting of amphibole-bearing wehrlites: an experimental study on the origin of ultra-calcic nepheline-normative melts, J. Petrol., 47, 481-504, 2006.

Médard, E., McCammon, C. A., Barr, J. A., and Grove, T. L.: Oxygen fugacity, temperature reproducibility, and $\mathrm{H}_{2} \mathrm{O}$ contents of nominally anhydrous piston-cylinder experiments using graphite capsules, Am. Mineral., 93, 1838-1844, 2008.

Michael, P. J., Langmuir, C. H., Dick, H. J. B., Snow, J. E., Goldstein, S. L., Graham, D. W., Lehnert, K., Kurras, G., Jokat, W., Muhe, R., and Edmonds, H. N.: Magmatic and amagmatic seafloor generation at the ultraslow-spreading Gakkel ridge, Arctic Ocean, Nature, 423, 956, 2003.

Montanini, A. and Tribuzio, R.: Evolution of recycled crust within the mantle: constraints from the garnet pyroxenites of the External Ligurian ophiolites (northern Apennines, Italy), Geology, 43, 911-914, 2015.

O'Hara, M. J.: Data reduction and projection schemes for complex compositions, in: Progress in Experimental Petrology, edited by: EaM, U., NERC, Manchester, Edinburgh, 103-126, 1972.

Pearson, D. G. and Nowell, G. M.: Re-Os and Lu-Hf isotope constraints on the origin and age of pyroxenites from the Beni Bousera peridotite massif: implications for mixed peridotitepyroxenite mantle source, J. Petrol., 45, 439-455, 2004.

Pertermann, M. and Hirschmann, M. M.: Anhydrous partial melting experiments on MORB-like eclogite: phase relations, phase compositions and mineral-melt partitioning of major elements at 2-3 GPa, J. Petrol., 44, 2173-2201, 2003a.

Pertermann, M. and Hirschmann, M. M.: Partial melting on a MORB-like pyroxenite between 2 and $3 \mathrm{GPa}$ : Constraints on the presence of pyroxenite in basalt source regions from solidus location and melting rate, J. Geophys. Res., 108, 2125, $2003 \mathrm{~b}$.

Phipps Morgan, J.: Thermodynamics of pressure release melting of a veined plum pudding mantle, Geochem. Geophys. Geosyst., 2, 2000GC000049, https://doi.org/10.1029/2000GC000049, 2001.

Pickering-Witter, J. and Johnson, A. D.: The effects of variable bulk composition on the melting systematics of fertile peridotitic assemblages, Contrib. Mineral. Petrol., 140, 190-211, 2000. 
Pilet, S., Baker, M. B., and Stolper, E. M.: Metasomatized lithosphere and the origin of alkaline lavas, Science, 320, 916, 2008.

Ringwood, A. E. and Green, D. H.: An experimental investigation of the gabbro-eclogite transition and some geophysical implications, Tectonophysics, 3, 383-427, 1966.

Rosenthal, A., Yaxley, G. M., Green, D. H., Hermann, J., Kovacs, I., and Spandler, C.: Continuous eclogite melting and variable refertilization in upwelling heterogeneous mantle, Sci. Rep., 4, 6099, 2014.

Rosenthal, A., Yaxley, G. M., Crichton, W. A., Kovacs, I. J., Spandler, C., Hermann, J., Sandornè, J. K., Rose-Koga, E., and Peleter, A.-A.: Phase relations and melting of nominally "dry" residual eclogites with variable $\mathrm{CaO} / \mathrm{Na}_{2} \mathrm{O}$ from 3 to $5 \mathrm{GPa}$ and 1250 to $1500^{\circ} \mathrm{C}$; implications for the refertilisation of the upwelling heterogeneous mantle, Lithos, 314-315, 506-519, 2018.

Shorttle, O. and Maclennan, J.: Compositional trends of Icelandic basalts: Implications for short-length scale lithological heterogeneity in mantle plumes, Geochem. Geophys. Geosyst. 12, Q11008, https://doi.org/10.1029/2011GC003748, 2011.

Shorttle, O., Maclennan, J., and Lambart, S.: Quantifying lithological variability in the mantle, Earth Planet. Sci. Lett., 395, 24-40, 2014.

Schutt, D. L. and Lesher, C. E.: Effects of melt depletion on the density and seismic velocity of garnet and spinel lherzolite, J. Geophys. Res., 111, B05401, https://doi.org/10.1029/2003JB002950, 2006.

Sobolev, A. V., Hofmann, A. W., Sobolev, S. V., and Nikogosian, I. K.: An olivine-free mantle source of Hawaiian shield basalts, Nature, 434, 590-597, 2005.

Sobolev, A. V., Hofmann, A. W., Kuzmin, D. V., Yaxley, G. M., Arndt, N. T., Chung, S.-L., Danyushevsky, L. V., Elliott, T., Frey, F. A., Garcia, M. O., Gurenko, A. A., Kamenetsky, V. S., Kerr, A. C., Krivolutskaya, N. A., Matvienkov, V. V., Nikogosian, I. K., Rocholl, A., Sigurdsson, I. A., Sushchevskaya, N. M., and Teklay, M.: The amount of recycled crust in sources of mantlederived melts, Science, 316, 412-417, 2007.

Spandler, C., Yaxley, G. M., Green, D. H., and Rosenthal, A.: Phase relations and melting of anhydrous K-bearing eclogite from 1200 to $1600^{\circ} \mathrm{C}$ and 3 to $5 \mathrm{GPa}$, J. Petrol., 49, 771-795, 2008.

Standish, J. J., Dick, H. J. B., Michael, P. J., Melson, W. G., and O'Hearn, T.: MORB generation beneath the ultraslow spreading Southwest Indian Ridge (9-25 E): major element chemistry and the importance of process versus source, Geochem. Geophys. Geosyst., 9, Q05004, https://doi.org/10.1029/2003JB002950, 2008.
Tilhac, R., Ceuleneer, G., Griffin, W. L., O’Reilly, S. Y., Pearson, N. J., Benoit, M., Henry, H., Girardeau, J., and Gregoire, M.: Primitive arc magmatism and delamination: petrology and geochemistry on pyroxenites from the Cabo Ortegal Complex, Spain, J. Petrol., 57, 1921-1954, 2016.

Tilhac, R., Gregoire, M., W. L., O’Reilly, Griffin, S. Y., Henry, H., and Ceuleneer, G.: Sources and timing of pyroxenite formation in the sub-arc mantle: case study of the Cabo Ortegal Complex, Spain, Earth Planet. Sci. Lett., 474, 490-4502, 2017.

Ulmer, P. and Luth, R. W.: The graphite fluid equilibrium in P, $\mathrm{T}$, $\mathrm{fO}_{2}$ space: an experimental determination to $30 \mathrm{kbar}$ and $1600^{\circ} \mathrm{C}$, Contrib. Mineral. Petrol., 106, 265-272, 1991.

Varas-Reus, M. I., Garrido, C. J., Marchesi, C., Bosch, D., and Hidas, K.: Genesis of ultra-high pressure garnet pyroxenites in orogenic peridotites and its bearing on the compositional heterogeneity of the Earth's mantle, Geochim. Cosmochim. Acta, 232, 303-328, 2018.

Walter, M. J.: Melting of garnet peridotite and the origin of komatiite and depleted lithosphere, J. Petrol., 39, 29-60, 1998.

Wasylenki, L. E., Baker, M. B., Kent, A. J. R., and Stolper, E. M.: Near-solidus melting of the shallow upper mantle: partial melting experiments on depleted peridotite, J. Petrol., 44, 1163-1191, 2003.

Wang, C., Ji, Z., Gao, S., Zhang, J., and Zheng. S.: Eclogitemelt/peridotite reaction: experimental constraints on the destruction mechanism of the North China Craton, Sci. China Earth Sci., 53, 797-809, 2010.

Wang, C., Lo Cascio, M., Liang, Y., and Xu, W.: An experimental study of peridotite dissolution in eclogite-derived melts: implications for styles of melt-rock interaction in lithospheric mantle beneath the North China Craton, Geochim. Cosmochim. Acta, https://doi.org/10.1016/j.gca.2019.09.022, in press, 2019

Yasuda, A., Fujii, T., and Kurita, K.: Melting phase relations of an anhydrous mid-ocean ridge basalt from 3 to $20 \mathrm{GPa}$ : implications for the behavior of subducted oceanic crust in the mantle, J. Geophys. Res., 99, 9401-9414, 1994.

Yaxley, G. M. and Green, D. H.: Reactions between eclogite and peridotite: mantle refertilisation by subduction of oceanic crust, Schweiz. Mineral. Petrogr. Mitt., 78, 243-255, 1998.

Yaxley, G. M. and Sobolev, A. V.: High-pressure partial melting of gabbro and its role in the Hawaiian magma source, Contrib. Mineral. Petrol., 154, 371-383, 2007. 